\title{
How can employment relations in global value networks be managed towards social
} responsibility?

\author{
Markus Helfen, Freie Universität Berlin \\ Elke Schüßler, Johannes Kepler University Linz \\ Jörg Sydow, Freie Universität Berlin
}

\section{Draft version. Final version forthcoming in Human Relations.}

\begin{abstract}
Ensuring social responsibility is a continued challenge in value creation processes that are globally dispersed among multiple organizations. We use the literature on interorganizational network management to shed new light on the question of how employment relations can be managed more responsibly in global value networks (GVN). In contrast to the structureoriented global value chain perspective, a network management perspective highlights the practices by which employment relations can be addressed in the context of plural forms of network governance. Using examples of GVN in the automotive and garment industries we illustrate how the network management practices of selecting, allocating, regulating and evaluating can enable lead firms and suppliers to effectively deal with social responsibility challenges on the level of whole networks. We also discuss how network management practices can address field-level and firm-level constraints for the management of multiemployer relations in GVN.
\end{abstract}

\section{Keywords}

employment relations, labour standards, global value networks, corporate social responsibility, multi-employer relations, network management, network governance 
Human tragedies like the suicides at the Foxconn factories in China (Chan et al., 2013) or the collapse of the Rana Plaza factory complex in Bangladesh (Reinecke and Donaghey, 2015; Schüßler et al., forthcoming) highlight the challenge of ensuring social responsibility, that is „compliance with societal expectations” (Scherer and Palazzo, 2011), in globally dispersed processes of value creation. In the light of the ongoing critique of firms' unilateral Corporate Social Responsibility (CSR) commitments (e.g. Locke et al., 2007) and the difficulties to reform international law (e.g. Weiss, 2013), current suggestions for fostering responsibility across firms' value chains focus on the broader web of actors involved in their governance. One suggestion highlights consumer movements as a force that, assisted by new technological possibilities in the social media, can directly leverage the symbolic vulnerability of globally sourcing brands (e.g. Donaghey et al., 2014). However, even lead firms that are willing to enhance social responsibility - possibly in response to consumer pressure - face severe limitations in managing suppliers' practices (e.g. Locke et al., 2009), not least because suppliers typically work for multiple buyers. In the midst of current debates about public and private regulation of globalized production (see Fransen and Burgoon, 2017 for a recent overview), we miss a decidedly managerial perspective that acknowledges management's possibilities for, and constraints in, managing employment relations across organizational and geographical boundaries.

Different theoretical concepts ranging from Global Commodity Chains (GCC) to Global Value Chains (GVC) and Global Production Networks (GPN) have so far neglected to systematically consider the management of labour and employment relations (Rainnie et al., 2011; Lakhani et al., 2013). Without questioning the analytical value of the GVC perspective (see e.g. Gibbon et al., 2008) or the critical value of the GPN perspective (see e.g. Levy, 2008) for other purposes, we think that both have different weaknesses regarding questions of managing employment relations. The GVC view tends to focus on the modes of governing - 
often dyadic - buyer-supplier relationships between firms (Gereffi, 1994, 2001). The resulting configurations of buyer-supplier relations assist in differentiating employment systems in different network-participating firms (Lakhani et al., 2013), but do not enhance our understanding of the challenge of managing employment relations across organizational boundaries. The GPN view points to the multiple interconnected economic and noneconomic actors involved in global production (Coe et al., 2008; Yeung and Coe, 2015: 32), but is not suited to analyse the management of employment relations across organizational boundaries (Lakhani et al., 2013).

In this paper, we propose to overcome these weaknesses by focusing on the interfirm networks at the heart of global value creation. Moving beyond the GVC perspective, we highlight that these networks are not only marked by different dominant forms of buyersupplier relations between firms (Gereffi et al., 2005; Lakhani et al., 2013), but also comprise "plural forms" of governance across the whole network (Bradach, 1997; Parmigiani, 2007), all of which bring along multi-employer relations. Yet, we avoid the pitfalls of the allencompassing GPN approach by concentrating more narrowly on the network of actors involved in value creation (and appropriation) and the resulting employment relations. For this purpose, we use the term global value network (GVN) (Glückler and Panitz, 2016: 1165) to denote that value creation processes take place in interorganizational networks that cross national boundaries. This framework allows us to address the question of how managing multi-employer relations in GVN can contribute to network social responsibility, for instance regarding core labour standards.

We first discuss extant attempts at integrating employment relations into the GVC/GPN literature and propose to acknowledge the centrality of multi-employer relations (Marchington et al., 2011; Rubery et al., 2005), i.e. employment arrangements in which workers are faced with conditions set beyond the confines of their direct employer, as a 
managerial challenge in GVN. Second, we introduce an interorganizational network management perspective inspired by structuration theory (e.g. Sydow and Windeler, 1998; Sydow et al., 2016) and explain how the network management practices of selecting, allocating, regulating and evaluating can affect multi-employer relations in GVN. By using the automotive and garment industries as contrasting examples we illustrate how plural modes of network governance and multi-employer relations can be reproduced and, eventually, transformed by network management practices. Third, we develop a model of network responsibility that acknowledges the interplay between network management practices and the firm-level and field-level structures in which they are embedded. Finally, we discuss the contributions that can be derived from our re-conceptualization: a practiceoriented rather than structure-oriented view on the governance of GVN marked by multiemployer relations; a consideration of the possibilities for and limitations of managerial agency in GVN; and a strengthening of network-based approaches towards the management of employment relations.

\section{Building blocks for conceptualizing employment relations in GVN}

Globally dispersed subcontracting structures are often explicitly formed to exploit differences in employment regulations (e.g. Chan et al., 2013; Lüthje and Butollo, 2017). Thus, a network-wide consideration and integration of employment relations has not been a management priority for buyers and suppliers (Lund-Thomsen and Lindgreen, 2014). Lead firms only selectively assume responsibility for their suppliers' workplace conditions (EgelsZandén, 2015), and force them into low-cost employment practices through their sourcing behaviour (e.g. Barrientos, 2013; Sydow and Frenkel, 2013). Factory owners, in turn, often face conditions that provide little leeway for more responsible practices (Young, 2004). In the light of repeated scandals and industrial accidents, however, lead firms and their suppliers 
face increasing pressure by clients, workers, unions and regulatory bodies to address social responsibility problems in their supply chains (e.g. Levy, 2008; Manning and Reinecke, 2016). In what follows we outline extant suggestions regarding the improvement of employment relations in GPN and GVC, respectively, before introducing our network management perspective.

\section{GPN perspective: Social responsibility through non-firm actors}

From a socio-economic perspective, the macro-level institutions of the economic system facilitate exploitative employment relations at the bottom of the pyramid (e.g. Barrientos, 2013; Palpacuer, 2008). From this perspective - which typically resonates with the GPN approach - pressure exerted by social movement organizations and trade unions could address the governance gap in global production contexts (e.g. Barrientos et al., 2011; Cumbers et al., 2008; Rainnie et al., 2011; Taylor et al., 2015). Outside pressure often results in various forms of private regulation (Bartley, 2007), revolving mainly around firm-driven codes of conducts. Widely criticised as inadequate (e.g. O'Rourke, 2003; Barrientos and Smith 2007), these tools have been complemented by multi-stakeholder initiatives (MSIs), ranging from those with rigorous standards and implementation procedures such as the Worker Rights Consortium (WRC) to industry-driven initiatives such as the Business Social Compliance Initiative (BSCI). These initiatives typically focus on ensuring minimal labour standards in GVN through auditing, monitoring and - in some cases - capacity building. Even strong MSIs, however, have been unable to detect process rights violations (EgelsZandén and Lindholm, 2015) and are thus limited in their effectiveness regarding social responsibility in GVN.

Recent initiatives strive for a more formally binding form by involving trade unions. One example is global framework agreements (GFAs) (e.g. Fichter et al., 2011; Hammer, 
2005; Helfen and Fichter, 2013) concluded between multinational enterprises (MNEs) and global union federations. The effectiveness of GFAs depends strongly on the respective management and union actors involved in their negotiation and implementation (Helfen et al., 2016). Further examples are contractual agreements negotiated between buyers, suppliers, and unions that make buyers as a group legally liable for their suppliers' employment standards (Anner et al., 2013), as well as the path-breaking Accord for Fire und Building Safety in Bangladesh (hereafter Accord) signed by over 200 garment brands and two global union federations (Donaghey and Reinecke, 2017). These initiatives are promising from a network management perspective, because they begin to acknowledge the nature of polyvalent GVN, characterized by plural forms of coordination, overlapping network membership, and embeddedness in multi-firm contexts, and the resulting challenges for managing employment relations.

\section{GVC perspective: Social responsibility from the structure of buyer-supplier relations}

From a GVC perspective, the managerial options for addressing responsibility concerns are limited by the structural constraints of different value chains (see the critique by Henderson et al., 2002; Lakhani et al., 2013). Providing the most comprehensive integration of employment relations into the GVC framework to date, Lakhani et al. (2013) build on Gereffi et al.'s (2005) GVC governance framework and map how different value chain configurations produce different employment systems for single firms in the chain. Gereffi and colleagues (2005: 87) distinguish five governance types based on ideal-typical bilateral buyer-supplier relationships distinguished by the complexity of transactions, the ability to codify transactions, and capabilities in the supply base. Apart from 'purely' market-driven or hierarchical configurations, GVC can comprise either relational, modular or captive modes of governing buyer-supplier relations. Whereas lead firms in hierarchical and captive GVC 
configurations are able to influence employment relations in dependent subsidiaries and suppliers, this influence is more limited in relational, modular or market modes because of the relative independence of suppliers.

Several studies support this view. Pedersen and Andersen (2006), for instance, illustrate how IKEA leverages its relative buying power and long-term, largely captive buyersupplier relationships to develop various kinds of safeguards against violations of its code of conduct. In contrast, Oka (2010) shows that market-based relationships mediated through sourcing agents were associated with poor labour standard compliance in the Cambodian garment sector. Several other studies of the automotive (e.g. Ponte and Sturgeon, 2014) and garment industries (e.g. Frenkel and Scott, 2002; Jiang, 2009; Locke and Romis, 2006) indicate that relational buyer-supplier relationships lead to better employment relations outcomes, because lead firms and suppliers face mutual interdependencies. While the GVC framework provides important building blocks for analysing how employment relations can be managed across organizational boundaries, it does not acknowledge the plurality of governance modes available in whole networks (Provan et al., 2007), the configuration of which can be actively shaped by network management practices.

\section{GVN perspective: Social responsibility from managing multi-employer relations}

In contrast to the structure-oriented GVC perspective and the externally oriented GPN perspective, a network management perspective, at least if rooted in structuration theory (Sydow and Windeler, 1998; Whittington, 1992; based on Giddens, 1984), focuses on how particular structures are produced, reproduced and eventually transformed on a whole network level by network management practices. Similar to the GVC perspective, a network management perspective assumes that, at their core, global production configurations consist of collaborative, sometimes hierarchy-like relationships between lead firms, such as buyers or 
producers (Gereffi, 2001), and led firms, such as suppliers and service providers, at different stages of the vertical value chain (Coe et al., 2008: 274). Implicitly, the competence and responsibility for developing governance structures that address employment relations issues is assigned to management in lead firms and suppliers; whether and how management takes on this responsibility is a matter of managerial strategic choice (e.g. Kochan et al., 1984), albeit under constraints set by labour law and unionization.

At the same time, a network management perspective assumes that GVN are marked by plural forms of governance (Bradach, 1997), combining market, hierarchy, and relational forms of coordination (Provan and Kenis, 2008). At the periphery of GVN, for instance, market-like transactions are typically more prevalent. A network management perspective hereby highlights that the practice of managing interfirm networks requires going beyond choosing the most adequate (network) governance structure. Rather, the management of employment relations in GVN is better understood as a practice which is enabled and restrained by the governance structure of whole networks as well as shaped through interdependent, but autonomous organizations in the network (Sydow and Windeler, 1998; Vangen and Huxham, 2011).

While the network management literature rarely deals with employment relations, the literature on multi-employer relations (Marchington et al., 2005, 2011) - not primarily concerned with global production - addresses the ways in which management engages with employment relations crossing organizational boundaries to achieve network-wide outcomes (Grimshaw and Rubery, 2005). The idea that employment relations are shaped by a multitude of (or even all) firms participating in the network is also captured by the term "networked working" (Swart and Kinnie, 2014: 293). Whereas Swart and Kinnie (2014) focus on professional service networks, other examples include (sub-)contractor-vendor-customer triads within multi-tier supply chain arrangements (Mena et al., 2013) and service delivery 
networks (Frenkel et al., 1999; Tax et al., 2013). From this perspective, responsible employment relations are a network-wide concern, regardless of whether lead firms, suppliers or intermediary service providers and work agencies are the legal employers (e.g. Cappelli and Keller, 2013; Havard et al., 2009; Marchington et al., 2005).

In large and complex interfirm networks - like those GVN that are marked by pronounced differences in the goals, skills, institutional backgrounds or identities of the participating organizations - achieving the alignment and integration of employment relations between the core and the periphery is particularly difficult (Marchington et al., 2011). In an early study of human resource management (HRM) in supply chains, Scarborough (2000) highlights that despite widespread buyer power over suppliers there is no unilateral influence of lead firms on supplier practices. Later work has shown that even across subsidiaries of the same multinational corporation it is difficult to transfer HRM practices because of institutional distance and legal independence of the unit (e.g. Ferner et al., 2012). In a GVN, shared practices thus only institutionalize to the extent that they rest on repeated interactions and network-wide expectations. Such management practices in turn also reproduce or transform network governance. With respect to social responsibility, several tensions are bound to arise because goals in networks, as well as the means to achieve these goals, are diverse and contested; for example, one supplier aims for price competition (more likely at the periphery), whereas another competes on issues of reliability or quality (more likely at the core). Thus, a common goal or aim, such as guaranteeing minimum labour standards or improving working conditions across firms collaborating in a GVN, must be defined, agreed upon and legitimized across the network (Black, 2008; Vangen and Huxham, 2011).

The practitioners directly involved in employment relations crossing multiple organizations are those actors who manage the network's workforce from within the GVN: managers in central HR departments - in particular, those in boundary spanning roles (cf. 
Langan-Fox and Cooper, 2014) - as well as HR managers of suppliers and service providers and, at least equally important, line managers and team and project leaders at the operative level. As employee voice is central to employment relations, workers and their representatives such as unions or works councils are - albeit with different presence depending on the institutional context - to be included on par (Kaufman, 2015). Both, labour and management actors, might form collective associations for network governance purposes.

\section{Shaping employment relations in GVN towards responsibility through network management practices}

Four "practice areas" have been considered to be of general importance for managing networks (Sydow and Windeler, 1998; Sydow et al., 2016): (1) Selecting, i.e. how the members of a network are chosen from the broader group of relevant firms, (2) Allocating, i.e. how resources and responsibilities are distributed within the network, (3) Regulating, i.e. how collaboration among the network's participants is defined and enforced, and (4) Evaluating, i.e. how participants, their contributions and relationships are assessed within the network and its institutional environment. These management practices, which are recursively interrelated, can be used to address employment relations in GVN (see Table 1 for an overview). A core value of the practice-oriented network management perspective is that it moves away from a relatively static understanding of agency resulting from structural pre-conditions (e.g. more or less unilateral power of lead firms vis-à-vis suppliers) towards understanding agency as an ongoing, collective and distributed practice that can either reproduce or change the structure of the whole network and thereby shapes network-level outcomes. Constrained, but also enabled by the structures of multiplex and plural interfirm relationships, this practice unfolds within complex processes of coordination, cooperation and 
negotiation among managers from lead firms and suppliers, possibly involving other actors as well.

Selecting the participants of a GVN is a core domain of managing multi-employer relations, because it heavily influences buyer-supplier relationships as well as horizontal interfirm relations. Selecting is a mutual process, but dominated by the more powerful firm. This practice consists of defining the terms for network participation such as entry points (i.e. full scope participation in all network activities or only for probationary activities), access rules to a network (i.e. common criteria to be met in order to qualify as a participant), and selection procedures as well as the scope of network overlap (i.e. whether multiple network memberships are tolerated or not). In addition, selecting extends to rules about the expulsion of members (deselecting). Thereby, selecting influences how difficult or easy it will be to develop a common understanding and to build trust depending on the network participants' homogeneity and heterogeneity.

Through the practice of allocating, i.e. how tasks, resources and responsibilities are distributed among the network's participants, GVN activities are guided towards achieving the network's goals as well as those of its participants, of course based on the present configuration of network partners. Again, allocating is dominated by the more powerful firm, usually equipped with more economic or symbolic resources resulting from a central position in the network (Gereffi, 1994).

Regulating focuses on issuing, shaping and enforcing the formal and informal rules of the GVN, i.e. the contracts as much as the connections in the network (Berends et al., 2011). Network regulation also includes goal-setting and involves issues of culture, ideology and power (Vlaar et al., 2007). Beyond mere adapting towards already institutionalized standards (e.g. ILO conventions), regulating entails the question of who effectively controls what kinds of resources for rule-setting, and of who decides how earnings are to be distributed in the 
interfirm network, thereby freezing or augmenting the resources available for re-allocation and stabilizing or challenging power constellations.

Selection, allocation and regulation activities often build upon evaluating network participants, relationships, practices and outcomes. These evaluations, which again are characterized by power asymmetries, go beyond "reflexive monitoring" (Giddens, 1984) and can include the contribution of firms towards achieving network responsibility as well as the establishment of appropriate employment relations practices. In what follows, we will discuss how selecting, allocating, regulating and evaluating can influence employment relations in automotive and garment GVN.

Insert Table 1 about here

Shaping employment relations in GVN in the automotive industry

GVN in car manufacturing are typically strategically led or "driven" by original equipment manufacturers (OEMs) as "producers", not (yet) by "buyers" such as retailers, as is common in the garment industry (Gereffi, 1994). Although global car manufacturing appears to be rather unified and integrated in processes and structures, not least because there are only a handful global OEMs dominating the market, GVN governance tends to vary by OEM strategy, country of origin or car model. In an older study, Choi and Hong (2002) mapped GVN by comparing first-tier and second-tier suppliers of DaimlerChrysler and Honda for three car models, and showed that in the final stage of car production (excluding indirect materials) between 85 per cent (Honda) and 70 per cent (Daimler) of parts were sourced from anything between 400 and 1,500 suppliers. First-tier suppliers themselves had large supply 
bases of between 65 and 300 suppliers, sourcing roughly a half of their parts from the outside, and even second-tier suppliers source relevant parts of their offers from the outside. Increasingly, OEM-independent online platforms are used for sourcing (Gereffi, 2001). Frigant (2011) reports findings of a survey on 750 French suppliers, showing that about 40 per cent of them operate on multiple tiers simultaneously (e.g. delivering complex components to OEMs as well as parts to tier 2 or 3 suppliers), indicating that automotive GVN are more densely connected and less hierarchically structured at their core than commonly assumed. Figure 1 depicts an exemplary automotive supply chain marked by plural forms of governance.

Insert Figure 1 about here

Network governance in car manufacturing leans towards relational governance at the core of the GVN's major transplant networks, i.e. local networks between OEM subsidiaries and system suppliers, that are similar to each other in structure and composition (Mair, 1994); at the peripheries, governance shows more captive and market-like sourcing of parts and industrial services (Sako and Helper, 1992). However, plural forms in car manufacturing GVN reach far beyond a binary core/periphery-model, because value creation is not only plural in terms of their "vertical" supply chain, but also horizontally due to collaborative $\mathrm{R} \& \mathrm{D}$, collective sourcing and co-production arrangements among competitors (Fusco and Spring, 2003). Additionally, the share of external service provision in cleaning, catering or recycling, but also in production itself has increased significantly, numbering in the extreme up to two thirds of the entire workforce on large production sites (Helfen, 2013).

In their transplants, OEMs thus duplicate a myriad of contracting forms in which regular employment within internal units coexists side-by-side with temporary or contract 
work governed either in the captive mode or by relational contracting with suppliers with varying degrees of buyer involvement. For example, if spot market contracts are used for sourcing simple parts, supplier employment relations face low buyer involvement. In contrast, where complex machinery maintenance requires service providers to be present permanently on the buyers' premises, buyers are highly involved in managing suppliers' employment relations. Sometimes, external service providers even develop the new product (outsourced engineering and design) and plant equipment manufacturers operate the equipment for a client on site (e.g. spraying parts and chassis). Like OEMs, system suppliers also operate their own temporary work arrangements using a mix of relational, captive and market-based ties on-site.

Automotive GVN are more criticized for a lack of environmental rather than social responsibility (Wilhelm et al., 2016), but factory accidents, such as a deadly blast in a GM supplier factory in China 2014 killing over 60 people, do occur, in addition to extensive product recalls due to quality problems (e.g. Camuffo and Wilhelm, 2016). Both indicate a lack of integration of, for instance, worker safety and training standards across the GVN. The following network management practices could support a tighter integration.

In the automotive industry, defining common selection criteria and procedures for suppliers is a joint affair of the dominant players, i.e. participating OEMs and system suppliers, and OEMs increasingly involve themselves in selecting even second-tier suppliers to secure quality and price (e.g. Choi and Linton, 2011). However, the predominance of a relational governance mode also means that lead firms only have a moderate influence on the employment relations of these first-tier suppliers, which have become powerful global firms themselves, marked by a high skill level and stability of employment for core workers (Jürgens and Krzywdzinski, 2014). Deselecting system suppliers according to predetermined selection criteria is usually not an option because of high relation-specific investments, so 
that supplier development is a widespread practice in the automotive industry. However, firsttier suppliers in multi-tier GVN can take up a "double agency" role and disseminate lead firms' sustainability standards across GVN, for instance by increasing information transparency among second-tier or third-tier suppliers and monitoring their sustainability performance (Wilhelm et al., 2016). Thus, selecting and developing first-tier suppliers according to social responsibility criteria, not least by examining their network of subsuppliers and their network management practices in use, could contribute to aligning employment relations standards from the core to the periphery. The same holds for service providers, where business relationships range from closely collaborating professional engineering firms to facility service providers operating at minimum wages. Since the latter are easier to substitute, deselection based on social responsibility performance could be used.

The allocation of resources, tasks, and responsibilities in principle allows for defining network-wide competences jointly and for organizing the exchange of the respective practices across the network. This sort of allocation can be observed where management, based on a more collaborative understanding about how to use network resources, provides joint training initiatives to improve local labour standard compliance (Sydow et al., 2014). This outcome, which Herrigel, Wittke and Voßkamp (2013) observe among OEMs and car manufacturers in China, is more likely under the more hierarchical modes of governance within corporate groups, but also possible with relational suppliers. Only in exceptional cases, however, do such joint development activities spill-over into support for the suppliers that operate in the periphery under the captive or the market mode and affect the jobs in these firms. As Wilhelm et al. (2016) show in other industries, allocating resources for first-tier suppliers to employ sustainability managers and carry out tasks of monitoring employment relations among sub-suppliers enhance their agency at crucial nodes within the GVN. 
With respect to regulating employment relations in GVN, negotiations in the relational mode often concern work processes and contracts involving safety and health issues, but also process design and quality, and extend to rules about working conditions and employment relations conducive to that end. OEMs in car manufacturing try, for example, to set network-wide standards through supplier workshops, which are geared towards redefining the terms for buyer-supplier interactions (e.g. Palmer et al., 2015; Aoki and Wilhelm, 2018). Another form of regulation would be the implementation of adequate voice mechanisms and employee representation from below to ensure a fair distribution of relational advantages throughout the network (Fichter et al., 2011). In the captive and modular modes, the imposition of standards and rules can be supported by GFAs, concluded for instance by VW, Renault, and Daimler. In MNEs, certain employment relations practices could be enforced through hierarchical fiat, for instance by including employment relations indicators in the incentive schemes for managers and replacing non-compliant local management. More indirectly, firms can tie foreign direct investment (FDI) to expectations regarding labour regulation in host countries (Mosley and Uno, 2007). Similarly, rotating HR managers across subsidiaries - and suppliers where appropriate - could align of employment relations, as would the respective training of new managers in employment relations issues. These opportunities for imposing rules are significantly reduced where more market-like governance modes prevail that involve independent suppliers. Nevertheless, options for influencing via contract renewal might exist.

The evaluation of interorganizational relations with an eye on employment relations may either lead to the improvement of working conditions or the discontinuation of the supplier relationship. In the relational mode, the network partners should ideally be involved via multi-level dialogue respecting organizational jurisdictions. This might extend to specifying work-related training measures and a proper composition of members in buyer- 
supplier project teams. In the captive and modular mode, much depends on the degree of divergence in terms of high-road or low-road HRM policies (Jürgens and Krzywdzinski, 2009). Where advantages are to be captured by segmenting the workforces into suppliers and core workforces, joint evaluation criteria are difficult to define, although it would be possible to evaluate a set of core criteria regarding employment relations from the whole network perspective. Depending on the institutional environment in which the lead organization operates, such criteria might include presence of union participation and employee representation. In the captive mode, apart from union grievances, evaluation instruments such as regular supplier audits, joint management-union assessments and fact-finding missions could be deployed to move car manufacturers beyond a mere passive, issue-driven policing of their responsibility commitments.

\section{Shaping employment relations in GVN in the garment industry}

Garment manufacturing GVN are generally dominated by large and powerful retailers or brand marketers which either coordinate a large network of globally dispersed suppliers themselves, operate through agents and importers, or use a mix of these governance modes. Compared to the automotive industry, the global garment industry is far more heterogeneous regarding firm size and global dispersion; market-like modes also seem more dominant in the garment sector (See Figure 2). Workers are typically low-skilled and female, making worker exploitation more likely. The GVN of brands/retailers targeting low price market segments often differ from those competing based on quality. In addition, GVN governance modes vary cross-nationally because of different industry histories (Lane, 2008). Some German brand manufacturers, for instance, still own production facilities and source most of their garments from Eastern Europe or Turkey rather than from Asia, favouring long-term, relational ties. This contrasts with major US retailers, which are described as being more 
footloose. But even within the same home country garment GVN can vary a great deal, with large retailers in Germany, for instance, working with anything between 11 and over 1000 factories (Schüßler and Lohmeyer, 2017). Most garment GVN, however, follow a clear coreperiphery model, with typically relational ties to core suppliers - which can variably be agents or large factories or a combination of both - and more market-based ties at the periphery including the suppliers of parts such as buttons or thread. Some large retailers also apply the hierarchical mode of governance when forming their own international sourcing offices, which often also organize the sourcing for other retailers; and others, typically in the low-price segment, frequently switch their sourcing agents in a more market-like mode.

A prevalent problem in this industry is the delegation of responsibility to agents which, often are themselves powerful global players coordinating a vast network of numerous suppliers. In contrast to the systems suppliers in the automotive industry, retailers can exert little pressure on the practices of these powerful intermediaries. An additional problem is the depth and global dispersion of the supply networks leading to the high incidence of uncontrolled sub-contracting to garment producers located in countries with the weakest labour laws. Again, brands strongly differ in this respect. When examining the few garment retailers that publish their supplier lists on their websites, it can be seen that the German sportswear brand adidas sources large amount of garments - both directly and through licensees - from Asian countries, whereas the Swedish garment retailer Nudie Jeans sources only 5 per cent of its garments from India, with the rest being sourced from Europe, Turkey and North Africa. Generally described as opaque because of their complexity (Egels-Zandén and Hansson, 2016), garment GVN fare low on both social and environmental responsibility, and are therefore frequently scrutinized by civil society actors (e.g. Bartley, 2007). Even firms that actively managed their supply networks towards more responsibility such as Nike 
in the light of external pressure faced severe limitations in achieving their aims (LundThomsen and Coe, 2015).

Insert Figure 2 about here

Regarding selection practices, reducing the number of relations to agents at the core of a GVN would be a basic step towards more responsibility in garment GVN. When working with agents, typically in a market-based or modular mode, retailers and brands could decide to select only those that follow strict supplier selection criteria, e.g. based on Business Social Compliance Initiative (BSCI) audits, and to choose suppliers in countries with stricter rather than weaker forms of labour regulation. However, stricter selection per se conflicts with aims such as cost-competitiveness and is no guarantee for more responsibility. Instead of relying on third-party information, buyers could resort to more relational means of (re-)selection such as getting to know their agents' supplier selection practices and establishing common norms and standards. For instance, retailers and their agents could mutually agree to source only from suppliers that have been inspected by the Accord in Bangladesh to ensure basic safety standards. In the case of direct sourcing relationships to factories, buyers could either strictly deselect suppliers in the case of non-compliance in the market mode, or they could engage in developing relational and captive supplier relations not only for process improvements, but also employment relations. Some smaller buyers have a practice of checking which other buyers are present in a given factory to ensure that they include those with a reputation for responsibility, thus leveraging knowledge from the GVN when making selection decisions. Additionally, longer buyer-supplier relations and shared investments lead to more trust, which is associated with better compliance with lead firm codes of conduct (Oka, 2010). Responses to recent factory accidents such as Rana Plaza indicate that some buyers 
increasingly opt for shorter supply chains with fewer, more integrated suppliers to which relational ties are developed to be in a better position to verify compliance with employment relation standards (Schüßler et al., forthcoming).

Selection practices, to be effective, typically need to be accompanied by practices of allocation. For instance, while many buyers in the garment industry now use "zero tolerance" selection criteria and enforce corrective action plans, they rarely support the supplier financially in implementing corrective measures (Frenkel et al., 2017). Paired with intense cost competition, this typically leads to faked audit data or unsolicited subcontracting. Again, consolidating the supply base towards fewer, but better equipped suppliers would make allocative measures effective. However, a move towards fewer, larger and more capable suppliers will also entail a shift from more captive to more relational modes of governance. Alternatively, quasi-externalized solutions could be an option to address employment relations in the suppliers' facilities by supporting employees to cope with multi-employer arrangements indirectly; for example through financing foundations for improving local health systems, housing or infrastructure. Buyers could also allocate more resources to internal audit staff and train sourcing managers in employment relations issues, making their consideration a part of their key performance criteria. Additionally, buyers can jointly invest in collective initiatives such as the Accord or the BSCI to foster industry-wide standardization of core labour standards.

This latter point ties into considerations about regulative measures and evaluation practices. In relational and captive modes, lead firms could foster goal congruence through incentives such as joint investments or exclusive contracts in the case of code compliance, or involving the suppliers in the development of the code. Buyers can also support the development of stronger forms of collective regulation to achieve certain standards even in market-based relationships. In all modes, the support for independent worker voice can play a 
crucial role. Oka (2016), for instance, showed in the case of garment suppliers in Cambodia that union presence improves the compliance of factories with wage, hours, and leave standards (but not health and safety). Supporting unionization in host countries, e.g. through actively creating a safe environment for employees seeking to unionize by granting them a financial safety web in case of dismissal. Such regulations are highly effective, especially since local unionization is widely considered as a necessary complement to lead firm-driven approaches such as GFAs, for instance concluded by Inditex (Miller, 2011), or the Accord (Labowitz and Baumann-Pauly, 2015; Zajak, 2017). Conversely, the kinds of collective bargaining contracts envisioned by Anner and colleagues (2013) appear to be more suited for relational and captive modes of governance. Given the higher number of suppliers in the garment industry, evaluating needs to move beyond firm-based audits towards leveraging outside sources of control by consumers, unions or agencies, which themselves need to develop network management strategies and practices (Bartley and Egels-Zandén, 2015). These should be complemented by regular site visits, which are again most feasible in the more long-term captive or relational modes of governance.

\section{A framework for managing employment relations in GVN for network responsibility}

The above examples illustrate a plurality of governance forms in GVN and their potential to be transformed over time. This leads us to propose a framework for managing multiemployer relations in GVN towards responsibility that considers different modes of network governance (See Figure 3). In our framework, network responsibility depends on the extent to which network members align with each other by selecting network participants, regulating their joint activities, allocating resources, and evaluating goal achievement with regards to a set of jointly shared objectives at the network level (Provan and Milward, 1995). Network responsibility hereby has to become an intermediary objective on a whole network level, i.e. 
a shared goal which is both instrumental and instrumented (Vangen and Huxham, 2011) for changing GVN governance and network management practices. Lead firms, suppliers and service providers in automotive GVN, for example, face the tension of meeting cost reduction and flexibility demands, while at the same time having to build reputation as socially responsible employers. Network management could work towards the goal of achieving these targets simultaneously, because labour risks often overlap with other types of risks in networks such as product quality, regulatory, and environmental risks (Sydow and Frenkel, 2013; Yeung and Coe, 2015).

Insert Figure 3 about here

The possibilities for managing GVN towards network responsibility depend on several context conditions. As the above examples show, tensions easily arise from membership in more than one GVN. Also, the wider field-level context and firm-level conditions complicate, but might also facilitate, the management of multi-employer relations across organizational boundaries. At the field level, multiple institutional demands regarding employment relations arise from customer or other stakeholder expectations, prevailing industry norms, or local culture and regulation (Coe et al., 2008; Levy, 2008; Scherer et al., 2013; Yeung and Coe, 2015). For example, in the garment industry, the current focus is seemingly to ensure worker safety, whereas product safety is a stronger concern in the automobile industry, likely with different implications for the management of employment relations in GVN. Also, local industrial relations regulations such as the chances for democratic workplace representation, the opportunities for collective bargaining, the scope of legal entitlements for migrant workforces and proper labour inspections (Lüthje and Butollo, 2017), but also living wages (Miller and Hohenegger, 2017) shape multi-employer relations. These regulations can be 
influenced at least to some extent by lead firm practices and improved by means of local participation in network governance (Lund-Thomsen and Lindgreen, 2014).

At the firm level, employment relations are influenced by organizational size as an indicator of resource endowment, as well as by the strategies, structures and cultures of the participating organizations. A business model focused on maximizing profits based on lowpriced standardized products hardly prioritizes investing in costly HRM or employment practices, whereas a differentiation strategy based on technological innovation and/or complementary services typically increases the scope of strategic choices, not least with respect to HRM and employment relations. Where the latter firms "export" their understanding of how to manage employment relations in a socially responsible way, they also influence the whole network - or at least significant parts of it - into a direction of network responsibility. In the context of HRM, Koulikoff-Souviron and Harrison (2008) highlight that firms' practices reflect different and possibly conflicting regulative, normative and cognitive institutions that could lead to the de-institutionalization of buyer-supplier relationships over time. In this respect, the once popular notion of an "extended enterprise" (Dyer, 2000) acquires a new meaning: "extended" also in terms of network responsibility for social concerns.

\section{Discussion and conclusion}

In this paper, we provide a managerial perspective on GVN as a complement to extant attempts to locate labour and employment issues more prominently within the prevailing GVC/GPN literatures (e.g. Lakhani et al., 2013; Rainnie et al., 2011; Yeung and Coe, 2015). Following recent perspectives that focus on lead firms in GVN as a source of responsibility concerns (e.g. Anner et al., 2013; Donaghey et al., 2014), we argue that managers in GVN are 
able to, and responsible for, managing multi-employer relations in GVN through adequate network management practices. Our framework enriches these debates in three ways.

First, expanding Lakhani et al.’s (2013) framework, we consider GVN as comprising plural forms of governance that do not structurally determine employment relations in single firms, because employment relations can be potentially transformed by network management practices directed at the whole network level. We thus suggest treating the GVN as a manageable entity; including all the difficulties and constraints regarding employment relations that this might entail. Our structurationist approach to network management complements earlier GVC governance perspectives by emphasizing a new, interorganizational level of employment relations research - and also HRM research, for that matter (e.g. Björkmann et al., 2014; Kinnie et al., 2005; Kroon and Paauwe, 2014, Marchington et al., 2005, 2011) - by going beyond 'single firm'-approaches. This is an important supplement to the discussion, because it allows us to understand where the network-related responsibility challenges for management stem from and why single-firm or dyadic management attempts usually fail to bring more social responsibility into GVN, even against best intentions. Extending commitment- and compliance-oriented approaches towards governing supply chains (e.g. Locke, 2013; Lund-Thomsen and Lindgreen, 2014), a network management perspective treats goals - such as social responsibility - not as given, but emphasizes the need for "making aims" (Huxham and Vangen, 2005) in a whole network context.

Second, our framework sheds light on the management set of actors - enabled and constrained by embeddedness in varying firm and institutional environments - that play a role in managing employment relations in GVN: CSR managers or HR managers in corporate headquarters as well as line and staff managers of HR in all networked firms (Lengnick-Hall and Lengnick-Hall, 2003). We also include intermediary forms of HR professionalism (Bonet 
et al., 2013; Gospel and Sako, 2010) that can increasingly assume a network-oriented role. Even the individual shop floor managers in supplier factories who - to date - face grossly contradictory demands regarding employment relations, can contribute to network responsibility, if only by raising concerns and awareness about the factory reality they observe. These actors and their - albeit within divergent limits and reach - agency in negotiating with unions and workers is largely overlooked by GPN analyses that tend to focus on actors that place outside pressure on lead firms such as consumers or NGOs. From a management view, the realization of this scope for action affords a distinct model of how to practice employment relations and manage multi-employer relations, i.e. network-compatible (e.g. by being aware of interconnectedness), less hierarchical (e.g. by involving various network participants' managers), more collaborative (e.g. by negotiating with unions) and yet more binding (e.g. by upholding network-wide rules).

Third, our framework also contributes to the employment relations and HRM literatures more broadly, which are only beginning to take network configurations and governance modes seriously (e.g. Kinnie et al., 2005; Swart and Kinnie, 2014). Problems of enforcement, for instance, concern not only minimal standards in adverse institutional environments (e.g. Locke et al., 2007, 2009), but also the implementation of high-end HRM practices, as the literature on practice transfer in multinational corporations has repeatedly shown (e.g. Ferner et al., 2012; Marchington and Wilkinson, 2012). Like the employment relations literature, also this literature would benefit from a reconsideration of "network modes" of governance (Provan and Kenis, 2008) rather than sticking with the "hierarchy vs. market"-dichotomy. We also expand on a socio-technical understanding of managing employment relations, as exhibited implicitly in the "HRM in the supply chain" literature (e.g. Fisher et al., 2010), by emphasizing the complex nature of managerial agency in GVN. The network management practices of selecting, allocating, evaluating and regulating are 
increasingly sought for in a "society of networks" (Raab and Kenis, 2009) and have the potential to actively change employment relations in GVN - and thereby to influence the outcome of networked activities beyond network responsibility.

As it stands, our approach is surely in need of broadening its empirical foundation beyond the limits of GVN in two exemplary and illuminative industry cases. Nevertheless, the differences among these two industries already pinpoint different pathways towards more responsible GVN through network management practices. In the automotive industry, the parallel trends towards a pluralization of governance modes and on-site multi-employer relations are a profound challenge for ensuring these GVN' social responsibility. Beyond car manufacturing, it is very likely that these trends have already established roots in similar manufacturing sectors such as the aviation or the pharmaceutical industry. Inasmuch as the cores of these networks are more integrated and their skilled workforces have more options for voicing their concerns, adequate responses for managing employment relations under plural GVN governance might emanate from lead firms and system suppliers. In the garment industry, and in other industries GVN that are marked by a low-skill workforce and high fragmentation and global dispersion, and hence even more heavily pluralized governance, a movement towards fewer, more long-term and relational supplier relationships might be an option. However, leveraging collective buyer power, unionization, and state regulation, seem promising avenues towards more GVN responsibility where unfettered market governance prevails. A particularly important issue for future empirical research, also from a more processual practice perspective, is the membership of firms in multiple GVN, as multiemployer relations not only span across institutional contexts and industries, but also across different networks, involving diverse norms and regulations. Other research issues include how individual managers acting within these networks can be assisted to cope with the respective challenges (Ellinger and Ellinger, 2014). More research is certainly also needed on 
the limits of managerial agency in GVN and how these might be addressed by different regulatory alternatives. These alternatives range from how to extend joint liability in a contractual, but also legal sense to the potentialities of a rights-based approach that endows individual workers with a capacity for litigation (Davidov, 2015). Where management is not capable of contributing to responsibility, legal restrictions on the viable range of network governance practices could be installed, for instance by restricting network expansion in certain segments of the labour market. Additionally, consumers, NGO initiatives, the ILO and global union federations can clearly support network managers in issuing stronger norms for business conduct in GVN. In this regard, recent considerations of how meta-organizations could be engaged for CSR issues seem a promising avenue for further study (Marques, 2017; Berkowitz et al., 2017). Finally, our model is clearly biased towards research based on supply chain and network governance and practices around transatlantic lead firms. In the light of recent geo-political events, the approaches of lead firms headquartered in emerging economies such as China or India deserve closer consideration (cf. e.g. Demirbag et al., 2016; Shah et al., 2017).

\section{Funding}

We gratefully acknowledge funding by the Volkswagen Foundation for the Project "Changes in the Governance of Garment Global Production Networks: Lead Firm, Supplier and Institutional Responses to the Rana Plaza Disaster" under the "European and Global Challenges Program". Parts of the automotive industry case description draws on research funded by Hans-Böckler-Foundation, Düsseldorf [research grant 2011-466-2]. 


\section{References}

Anner M, Bair J and Blasi J (2013) Toward joint liability in global supply chains: Addressing the root causes of labor violations in international subcontracting networks. Comparative Labor Law and Policy Journal 35(1): 1-43.

Aoki K and Wilhelm M (2018) The role of ambidexterity in managing buyer-supplier relationships: The Toyota case. Organization Science, doi.org/10.1287/orsc.2017.1156.

Barrientos S (2013) 'Labour chains': Analysing the role of labour contractors in global production networks. Journal of Development Studies 49(8): 1058-1071.

Barrientos S, Mayer F, Pickles J and Posthuma A (2011) Decent work in global production networks: Framing the policy debate. International Labour Review 150(3-4): 299-317.

Barrientos S and Smith S (2007) Do workers benefit from ethical trade? Assessing codes of labour practice in global production systems. Third World Quarterly 28(4): 713-729.

Bartley T (2007) Institutional emergence in an era of globalization: The rise of transnational private regulation of labor and environmental conditions. American Journal of Sociology 113(2): 297-351.

Bartley T and Egels-Zandén N (2015) Beyond decoupling: unions and the leveraging of corporate social responsibility in Indonesia. Socio-Economic Review 14(2): 231-255.

Berends H, van Burg E and van Raaj EM (2011) Contacts and contracts: Cross-level network dynamics in the development of an aircraft material. Organization Science 22: 940-960.

Berkowitz H, Bucheli M and Dumez H (2017) Collectively designing CSR through metaorganizations: A case study of the oil and gas industry. Journal of Business Ethics 143: 753-769.

Björkmann I, Ehrnrooth M, Mäkelä K, Smale A and Sumelius J (2014) From HRM practices to the practice of HRM: setting a research agenda. Journal of Organizational Effectiveness 1(2): 122-140. 
Black J (2008) Constructing and contesting legitimacy and accountability in polycentric regulatory regimes. Regulation \& Governance 2: 137-164.

Bonet R, Cappelli P and Hamori M (2013) Labor market intermediaries and the new paradigm for human resources. Academy of Management Annals 7(1): 341-392.

Bradach JL (1997) Using the plural form in the management of restaurant chains. Administrative Science Quarterly 42(2): 276-303.

Camuffo A and Wilhelm M (2016) Complementarities and organizational (mis)fit: a retrospective analysis of the Toyota recall crisis. Journal of Organizational Design 5: 4.

Cappelli P and Keller JR (2013) Classifying work in the New Economy. Academy of Management Review 38(4): 575-596.

Chan J, Ngai P and Selden M (2013) The politics of global production: Apple, Foxconn and China's new working class. New Technology, Work and Employment 26(2): 100-115.

Choi TY and Hong Y (2002) Unveiling the structure of supply networks: Case studies in Honda, Acura, and DaimlerChrysler. Journal of Operations Management 20: 469-493.

Choi TY and Linton T (2011) Don't let your supply chain control your business. Harvard Business Review 89(12): 112-117.

Coe NM, Dicken P and Hess, M (2008) Global production networks: Realizing the potential. Journal of Economic Geography 8: 271-295.

Cumbers A, Nativel C and Routledge P (2008) Labour agency and union positionalities in global production networks. Journal of Economic Geography 8(3): 369-387.

Davidov G (2015) Indirect employment: Should lead companies be liable? Comparative Labor Law \& Policy Journal 37(5): 5-36.

Demirbag M, Tatoglu E and Wilkinson A (2016) Adoption of high performance work systems by local subsidiaries of developed country and Turkish MNEs and indigenous firms in turkey. Human Resource Management 55(6): 1001-1024. 
Donaghey J, Reinecke J, Nifourou C and Lawson B (2014) From employment relations to consumption relations: Balancing labour governance in global supply chains. Human Resource Management 53(2): 229-252.

Donaghey, J and Reinecke, J (2017) When industrial democracy meets corporate social responsibility - a comparison of the Bangladesh Accord and Alliance as responses to the Rana Plaza disaster. British Journal of Industrial Relations. DOI: 10.1111/bjir.12242.

Dyer JH (2000) Collaborative Advantage: Winning through Extended Enterprise Supplier Networks. Oxford: Oxford University Press.

Egels-Zandén N (2015) Responsibility boundaries in global value chains: Supplier audit prioritizations and moral disengagement among Swedish firms. Journal of Business Ethics. DOI 10.1007/s10551-015-2818-7.

Egels-Zandén N and Hansson N (2016) Supply chain transparency as a consumer or corporate tool: The case of Nudie Jeans Co. Journal of Consumer Policy, 39(4): 377395.

Egels-Zandén N and Lindholm H (2015) Do codes of conduct improve worker rights in supply chains? A study of Fair Wear Foundation. Journal of Cleaner Production 107: 31-40.

Ellinger AE and Ellinger AD (2014) Leveraging human resource development expertise to improve supply chain managers' skills and competencies. European Journal of Training and Development 38(1-2): 118-135.

Ferner A, Edwards T and Tempel A (2012) Power, institutions and the cross-national transfer of employment practices in multinationals. Human Relations 65(2): 163-187.

Fichter M, Helfen M and Sydow J (2011) Employment relations in global production networks - Initiating transfer of practices via union involvement. Human Relations 64(4): 599-624. 
Fisher SL, Graham ME, Vachon S and Vereecke A (2010) Don't miss the boat: Research on HRM and supply chains. Human Resource Management 49(5): 813-828.

Fransen, L and Burgoon, B (2017) Introduction to the Special Issue: Public and private labor standards policy in the global economy. Global Policy 8(3). In print.

Frenkel SJ, Korcynzski M, Shire, KA and Tam M (1999) On the Front Line. Organization of Work in the Information Economy. Cornell University Press: New York.

Frenkel SJ, Rahman KM and Rahman S (2017) Between lead firms and institutional ensembles: Labour and safety practices in Bangladeshi garment export factories. Garment Supply Chain Governance Discussion Paper Series No. 03/2017.

Frenkel SJ and Scott D (2002) Compliance, collaboration, and codes of labor practice: The ADIDAS connection. California Management Review 45(1): 29-49.

Frigant V (2011) Egyptian pyramid or Aztec pyramid: How should we describe the industrial architecture of automotive supply chains in Europe? Cahiers du GRETha No 2011-27. Université Montesquieu Bourdeaux IV.

Fusco JP and Spring M (2003) Flexibility versus robust networks. The case of the Brazilian automotive sector. Integrated Manufacturing Systems 14(1): 26-35.

Gereffi G (1994) The organization of buyer-driven global commodity chains: How US retailers shape overseas production networks. In Gereffi G and Korzeniewicz M (eds) Commodity Chains and Global Capitalism Westport, CT: Praeger, 95-122.

Gereffi G (2001) Beyond the producer-driven/buyer-driven dichotomy: The evolution of global value chains in the Internet era. IDS Bulletin 32(3): 31-40

Gereffi G, Humphrey J and Sturgeon T (2005) The governance of global value chains. Review of International Political Economy 12(1): 78-104.

Gibbon P, Bair J and Ponte S (2008) Governing global value chains: An introduction. Economy and Society 37(3): 315-338. 
Giddens A (1984) The Constitution of Society. Cambridge: Polity.

Glückler J and Panitz R (2016) Relational upgrading in global value networks. Journal of Economic Geography 16(6): 1161-1185.

Gospel H and Sako M (2010) The unbundling of corporate functions: the evolution of shared services and outsourcing in human resource management. Industrial and Corporate Change 19(5): 1367-1396.

Grimshaw D and Rubery J (2005) Inter-capital relations and the network organisation: redefining the work and employment nexus. Cambridge Journal of Economics 29: 10271051.

Hammer N (2005) International Framework Agreements: Global industrial relations between rights and bargaining. Transfer 11(4): 511-530.

Havard C, Rorive B and Sobczak A (2009) Client, employer and employee: Mapping a complex triangulation. European Journal of Industrial Relations 15(3): 257-276.

Helfen M (2013) Tertialisierung von Wertschöpfungsnetzwerken: Eine globale Herausforderung für die Gewerkschaften In Müller T and Rüb S (eds) Arbeitsbeziehungen im Prozess der Globalisierung und Europäischen Integration. Baden-Baden: Nomos, 81-96.

Helfen M and Fichter M (2013) Building transnational union networks across global production networks: Conceptualising a new arena of labour-management relations. British Journal of Industrial Relations 51(3): 553-576.

Helfen M, Schüßler E and Stevis D (2016) Translating European labor relations practices to the United States through Global Framework Agreements? German and Swedish multinationals compared. Industrial \& Labor Relations Review 69(3): 631-655.

Herrigel G, Wittke V and Voßkamp U (2013) The process of Chinese manufacturing upgrading: Transitioning from unilateral to recursive mutual learning relations. Global Strategy Journal 3(1): 109-125. 
Jiang G (2009) Implementing supplier codes of conduct in global supply chains: Process explanations from theoretical and empirical perspectives. Journal of Business Ethics 85: $77-92$.

Jürgens U and Krzywdzinski M (2009) Changing East-West division of labour in the European automotive industry. European Urban and Regional Studies 16: 27-42.

Jürgens U and Krzywdzinski M (2014) Competence development on the shop floor and industrial upgrading: case studies of automakers in China. International Journal of Human Resource Management 26(9): 1204-1225.

Kinnie NJ, Swart J and Purcell J (2005) Influences on the choice of HR system: the network organization perspective. International Journal of Human Resource Management 16(6): 1004-1028.

Kochan TB, McKersie RB and Cappelli P (1984) Strategic choice and industrial relations theory. Industrial Relations 23(1): 16-39.

Koulikoff-Souviron M and Harrison A (2008) Interdependent supply relationships as institutions: the role of $\mathrm{HR}$ practices. International Journal of Operations and Production Management 28(5): 412-432.

Kroon B and Paauwe J (2014) Structuration of precarious employment in economically constrained firms: the case of Dutch agriculture. Human Resource Management Journal 24(1): 19-37.

Labowitz S and Baumann-Pauly D (2015) Beyond the tip of the iceberg: Bangladesh's forgotten apparel workers. NYU Stern Center for Business and Human Rights Report.

Lakhani T, Kuruvilla S and Avgar A (2013) From the firm to the network: Global value chains and employment relations theory. British Journal of Industrial Relations 51(3): 440-472. 
Lane C (2008) National capitalisms and global production networks: an analysis of their interaction in two global industries. Socio-Economic Review 6(2): 1475-1461.

Langan-Fox J and Cooper G (eds) (2014) Boundary Spanning in Organizations: Network, Influence, and Conflict. London: Routledge.

Lengnick-Hall ML and Lengnick-Hall CA (2003) HR's role in building relationship networks. Academy of Management Executive 17(49): 53-63.

Levy DL (2008) Political contestation in global production networks. Academy of Management Review 33(4): 943-963.

Locke R (2013) The Promise and Limits of Private Power. Promoting Labor Standards in a Global Economy. New York: Cambridge University Press.

Locke RM and Romis M (2010) The promise and perils of private voluntary regulation: Labor standards and work organization in two Mexican garment factories. Review of International Political Economy 17: 45-74.

Locke RM, Amengual M and Mangla A (2009) Virtue out of necessity? Compliance, commitment and the improvement of labor conditions in global supply chains. Politics and Society 37(3): 319-351.

Locke RM, Qin F and Brause A (2007) Does monitoring improve labor standards: Lessons from Nike. Industrial \& Labor Relations Review 61(3): 3-31.

Lüthje B and Butollo F (2017) Why the Foxconn model does not die: Production networks and labor relations in the IT industry in South China. Globalizations 14(2): 216-231.

Lund-Thomsen P and Coe NM (2013) Corporate social responsibility and labour agency: the case of Nike in Pakistan. Journal of Economic Geography 15(2): 275-296.

Lund-Thomsen P and Lindgreen A (2014) Corporate Social responsibility in global value chains: Where are we now and where are we going? Journal of Business Ethics 123: 1122. 
Mair A (1994) Honda's global flexifactory network. International Journal of Operations \& Production Management 14(3): 6-23.

Manning S and Reinecke J (2016) A modular governance architecture in-the-making: How transnational standard-setters govern sustainability transitions. Research Policy, 45: 618633.

Marchington M and Wilkinson A (2012) Human Resource Management at Work (5th ed.). London: Chartered Institute of Personnel and Development.

Marchington M, Grimshaw D, Rubery J and Willmott H (2005) Fragmenting Work. Blurring Organizational Boundaries and Disordering Hierarchies. Oxford: Oxford University Press.

Marchington M, Rubery J and Grimshaw D (2011) Alignment, integration and consistency in HRM across multi-employer networks. Human Resource Management 50(3): 313-339.

Marques JC (2017) Industry business associations: Self-interested or socially conscious? Journal of Business Ethics 143: 733-751.

Mena C, Humphries A and Choi TY (2013) Toward a theory of multi-tier supply chain management. Journal of Supply Chain Management 49(2): 58-77.

Miller D (2011) Global social relations and Corporate Social Responsibility in outsourced apparel supply chains: The Inditex Global Framework agreement, In Papadakis K (ed) Shaping global industrial relations. The Impact of International Framework Agreements. Palgrave Macmillan: New York, 179-198.

Miller D and Hohenegger K (2017) Redistributing value added towards labour in apparel supply chains: Tackling low wages through purchasing practices. Conditions of Work and Employment series, No. 83. International Labour Office. Geneva.

Mosley L and Uno S (2007) Racing to the bottom or climbing to the top? Economic globalization and collective labor rights. Comparative Political Studies, 40(8): 923-948. 
Oka C (2016) Improving working conditions in garment supply chains: the role of unions in Cambodia. British Journal of Industrial Relations, 54(3): 647-672.

Oka C (2010) Channels of buyer influence and labor standard compliance: the case of Cambodia's garment sector. Advances in Industrial and Labor Relations 17: 153-183.

O'Rourke D (2003) Outsourcing regulation: Analyzing nongovernmental systems of labor standards and monitoring. Policy Studies Journal 31(1): 1-29.

Palmer M, Simmons G, Robinson PK and Fearne A (2015) Institutional maintenance work and power preservation in business exchanges: Insights from industrial supplier workshops. Industrial Marketing Management 48: 214-225.

Palpacuer F (2008) Bringing the social context back in: governance and wealth distribution in global commodity chains. Economy and Society 37(3): 393-419.

Paquin RL and Howard-Grenville J (2013) Blind dates and arranged marriages: Longitudinal processes of network orchestration. Organization Studies 34(11): 1623-1653.

Parmigiani A (2007) Why do firms both make and buy? An investigation of concurrent sourcing. Strategic Management Journal 28(3), 285-311.

Pedersen ER and Andersen M (2006) Safeguarding corporate social responsibility in global supply chains: how codes of conducts are managed in buyer-supplier relationships. Journal of Public Affairs, 6: 228-240.

Ponte S and Sturgeon T (2014) Explaining governance in global value chains: A modular theory-building effort. Review of International Political Economy 21(1): 185-223.

Provan KG, Fish A and Sydow J (2007) Interorganizational networks at the network level: A review of the empirical literature on whole networks. Journal of Management 33(3): 479-516.

Provan KG and Kenis P (2008) Modes of network governance: Structure, management, and effectiveness. Journal of Public Administration Research and Theory 18: 229-252. 
Provan KG and Milward HB (1995) A preliminary theory of interorganizational network effectiveness: A comparative study of four community health systems. Administrative Science Quarterly 40(1): 1-33.

Raab J and Kenis P (2009) Heading toward a society of networks: Empirical developments and theoretical challenges. Journal of Management Inquiry 18(3): 198-210.

Rainnie A, Herod A and McGrath-Champ S (2011) Review and positions: Global production networks and labour. Competition and Change 15(2): 155-169.

Reinecke J and Donaghey J (2015) After Rana Plaza: Building coalitional power for labour rights between unions and (consumption-based) social movement organisations. Organization 22(5): 720-740.

Rubery J, Earnshaw J and Marchington M (2005) Blurring the boundaries to the employment relationship: From single to multi-employer relationships. In: Marchington M, Grimshaw D, Rubery $\mathrm{J}$ and Willmott $\mathrm{H}$ (eds) Fragmenting Work. Blurring Organizational Boundaries and Disordering Hierarchies. Oxford: Oxford University Press: 63-88.

Sako M and Helper S (1998) Determinants of trust in supplier relations: Evidence from the automotive industry in Japan and the United States. Journal of Economic Behavior and Organization 34: 387-417.

Scarbrough, H (2000) The HR implications of supply chain relations. Human Resource Management Journal 10(1): 5-17.

Scherer AG and Palazzo G (2011) The new political role of business in a globalized world: A review of a new perspective on CSR and its implications for the firm, governance, and democracy. Journal of Management Studies 48(4): 899-931.

Scherer AG, Palazzo G and Seidl D (2013) Managing legitimacy in complex and heterogeneous environments: Sustainable development in a globalized world. Journal of Management Studies 50(2): 259-284. 
Schüßler E., Frenkel S and Wright C (forthcoming) Focusing events and changes in the governance of labor standards in Australian and German garment supply chains. Industrial and Labor Relations Review.

Schüßler, E and Lohmeyer, N (2017) Changing Governance System for Labour: Germany's Garment Supply Chains. Garment Supply Chain Governance Discussion Paper Series No. 02/2017. Berlin: Freie Universität Berlin.

Shah D, Russell, B and Wilkinson A (2017) Opportunity and opportunism: The expatriate practices of Indian information technology multinational corporations. Journal of International Management 23(2): 139-150.

Swart, J and Kinnie, N (2014) Reconsidering boundaries: Human Resource Management in a networked world. Human Resource Management 53(2): 291-310.

Sydow J, Fichter M, Helfen M, Sayim KD and Stevis D (2014) Implementation of global framework agreements: Towards a multi-organizational practice perspective. Transfer, 20(4): 489-503.

Sydow J and Frenkel S (2013) Labor, risk and uncertainty in global supply networks Exploratory insights. Journal of Business Logistics 34(3): 233-242.

Sydow J, Schüßler E and Müller-Seitz G (2016) Managing Inter-organizational Relations: Debates and cases. London: Palgrave Macmillan.

Sydow J and Windeler A (1998) Organizing and evaluating interfirm networks: A structurationist perspective on network processes and effectiveness. Organization Science 9(3): 265-284.

Tax SS, McCutcheon D and Wilkinson IF (2013) The service delivery network (SDN): A customer-centric perspective of the customer journey. Journal of Service Research 16(4): 454-470. 
Taylor P, Newsome K, Bair J and Rainnie A (2015) Putting labour in its place: Labour process analysis and global value chains. In Newsome K, Taylor P, Bair J and Rainnie A (eds) Putting Labour in its place: Labour Process Analysis and Global Value Chains. London: Palgrave Macmillan, 1-26.

Vangen S and Huxham C (2011) The tangled web: Unraveling the principle of common goals in collaborations. Journal of Public Administration Research and Theory 22: 731-760.

Vlaar PWL, Van den Bosch FAJ and Volberda HW (2007) Towards a dialectic perspective on formalization in interorganizational relationships: How alliance managers capitalize on the duality inherent in contracts, rules and procedures. Organization Studies 28(4):437-466.

Weiss M (2013) International labour standards: A complex public-private policy mix. International Journal of Comparative Labour Law and Industrial Relations 29(1): 7-19.

Whittington R (1992) Putting Giddens into action: Social systems and managerial agency. Journal of Management Studies 29(6): 693 -712.

Wilhelm M, Blome C, Wieck E and Xiao CY (2016) Implementing sustainability in multitier supply chains: Strategies and contingencies in managing sub-suppliers. International Journal of Production Economics 182: 196-212.

Yeung HW and Coe NM (2015) Toward a dynamic theory of global production networks. Economic Geography 91(1): 29-58.

Young IM (2004) Responsibility and global labor justice. Journal of Political Philosophy 12(4): 365-388.

Zajak S (2017). International allies, institutional layering and power in the making of labour in Bangladesh. Development and Change 48(5): 1007-1030. 
Table 1: Managing multi-employer relations in global value networks (GVN) towards social responsibility: Exemplary practices

\begin{tabular}{|c|c|c|c|c|c|}
\hline & \multicolumn{5}{|c|}{ Focal GVN governance modes according to Gereffi et al. (2005) terminology } \\
\hline $\begin{array}{l}\text { Manage- } \\
\text { ment } \\
\text { practices }\end{array}$ & Market & Modular & Relational & Captive & Hierarchy \\
\hline Selecting & $\begin{array}{l}\text { Formalizing employment relations } \\
\text { as criteria for market governing } \\
\text { bodies, e.g. certification schemes, } \\
\text { strict supplier exclusion from } \\
\text { market in the case of violations } \\
\text { Sourcing from suppliers certified } \\
\text { by MSIs and/or located in } \\
\text { countries upholding basic labour } \\
\text { standards (e.g. freedom of } \\
\text { association) }\end{array}$ & $\begin{array}{l}\text { Formalizing employment relations } \\
\text { criteria for participation in the } \\
\text { network (e.g. freedom of } \\
\text { association), strict supplier } \\
\text { deselection in the case of } \\
\text { violations } \\
\text { Selecting suppliers which do not } \\
\text { only fit the standardized interfaces } \\
\text { but also comply with basic labour } \\
\text { standards }\end{array}$ & $\begin{array}{l}\text { Coordinating supplier selection } \\
\text { practices across member firms to } \\
\text { ensure congruence of employment } \\
\text { relations systems in the network } \\
\text { Selecting suppliers that strive for } \\
\text { long-term, trust-based } \\
\text { relationships } \\
\text { Supporting (e.g. financially or } \\
\text { through expertise) the upgrading } \\
\text { of suppliers regarding } \\
\text { employment relations }\end{array}$ & $\begin{array}{l}\text { Enforcing basic labour standards } \\
\text { (e.g. health \& safety, freedom of } \\
\text { association), using hierarchy-like } \\
\text { controls and threat of exit } \\
\text { Avoiding sourcing from countries } \\
\text { not upholding basic labour } \\
\text { standards } \\
\text { Incentivizing supplier } \\
\text { development, e.g. joint } \\
\text { investments; supporting suppliers } \\
\text { (e.g. financially or through } \\
\text { expertise) in implementing } \\
\text { corrective action }\end{array}$ & $\begin{array}{l}\text { Vertically integrating core } \\
\text { suppliers to gain more direct } \\
\text { influence } \\
\text { Relocating subsidiaries to host } \\
\text { countries upholding basic labour } \\
\text { standards } \\
\text { Selecting responsible country and } \\
\text { subsidiary managers }\end{array}$ \\
\hline Allocating & $\begin{array}{l}\text { Informing sourcing managers } \\
\text { about core employment relations } \\
\text { criteria and including these in } \\
\text { their KPI } \\
\text { Allocating resources to credible } \\
\text { market governing bodies }\end{array}$ & $\begin{array}{l}\text { Informing sourcing managers } \\
\text { about core employment relations } \\
\text { criteria and including these in } \\
\text { their KPI } \\
\text { Offering direct intervention on a } \\
\text { voluntary basis } \\
\text { Investing in monitoring }\end{array}$ & $\begin{array}{l}\text { Providing resources for network- } \\
\text { wide bodies for employee voice, } \\
\text { also for participation and conflict } \\
\text { resolution } \\
\text { Fostering mutual learning in joint } \\
\text { coordination teams or formal } \\
\text { steering committees about how to } \\
\text { organize for social responsibility } \\
\text { Supporting assignments and } \\
\text { regular site visits in the whole } \\
\text { network }\end{array}$ & $\begin{array}{l}\text { Incentivizing sourcing managers } \\
\text { to care about core employment } \\
\text { relations criteria and including } \\
\text { these in their KPI } \\
\text { Running workshops for } \\
\text { knowledge exchange between } \\
\text { participating firms } \\
\text { Training employees on } \\
\text { employment rights } \\
\text { Rewarding suppliers for costs of } \\
\text { compliance with code of conduct }\end{array}$ & $\begin{array}{l}\text { Including employment standards } \\
\text { in investment decision criteria } \\
\text { Incentivizing managers for } \\
\text { meeting social responsibility } \\
\text { criteria } \\
\text { Rotating HR managers across } \\
\text { subsidiaries to harmonize } \\
\text { employment relations } \\
\text { Training of new managers, } \\
\text { including those in subsidiaries, } \\
\text { regarding employment relations } \\
\text { issues }\end{array}$ \\
\hline Regulating & $\begin{array}{l}\text { Forming bodies, associations or } \\
\text { initiatives for devising clear rules } \\
\text { and sanctions regarding market } \\
\text { participation for buyers and } \\
\text { suppliers }\end{array}$ & $\begin{array}{l}\text { Defining network-related rules to } \\
\text { support responsible employment } \\
\text { relations }\end{array}$ & $\begin{array}{l}\text { Jointly developing network-wide } \\
\text { employment relations standards, } \\
\text { systems and policies } \\
\text { Participating in collective } \\
\text { initiatives and cooperation with }\end{array}$ & $\begin{array}{l}\text { Drafting contractual agreements } \\
\text { and sanctions to enforce basic } \\
\text { labour standards (e.g. health \& } \\
\text { safety); standardizing work } \\
\text { process \& quality } \\
\text { Involving suppliers in }\end{array}$ & $\begin{array}{l}\text { Replacing non-compliant local } \\
\text { management } \\
\text { Extending scope of employee } \\
\text { representation (e.g. World works } \\
\text { councils) }\end{array}$ \\
\hline
\end{tabular}




\begin{tabular}{|c|c|c|c|c|c|}
\hline & & & $\begin{array}{l}\text { other lead firms } \\
\text { Involving unions and third parties } \\
\text { in enforcing basic labour } \\
\text { standards (e.g. GFAs which } \\
\text { involve home and host country } \\
\text { unions) }\end{array}$ & development of code of conduct & $\begin{array}{l}\text { Influencing host country } \\
\text { institutional environments through } \\
\text { lobbying tied to FDI investments; } \\
\text { supporting local unionization }\end{array}$ \\
\hline Evaluating & $\begin{array}{l}\text { Monitoring price and quality } \\
\text { movements and other types of } \\
\text { market behaviour }\end{array}$ & $\begin{array}{l}\text { Leveraging feedback from } \\
\text { external stakeholders to influence } \\
\text { supplier behaviour with respect to } \\
\text { employment relations locally (e.g. } \\
\text { customers, agencies, unions) } \\
\text { Leveraging reputation effects } \\
\text { when supplier is embedded in } \\
\text { multiple GPN }\end{array}$ & $\begin{array}{l}\text { Engaging in a multi-level dialogue } \\
\text { in standard-setting procedures } \\
\text { regarding employment relations } \\
\text { Leveraging reputation effects } \\
\text { when supplier is embedded in } \\
\text { multiple GPN }\end{array}$ & $\begin{array}{l}\text { Supplier audits that take } \\
\text { employment relations into account } \\
\text { Supplier monitoring through } \\
\text { extended site visits } \\
\text { Using formal and informal } \\
\text { evaluation and feedback }\end{array}$ & $\begin{array}{l}\text { Regularly monitoring subsidiary } \\
\text { employment relations through } \\
\text { reporting, site visits and staff } \\
\text { rotation }\end{array}$ \\
\hline
\end{tabular}


Figure 1. GVN as a plural form in car manufacturing

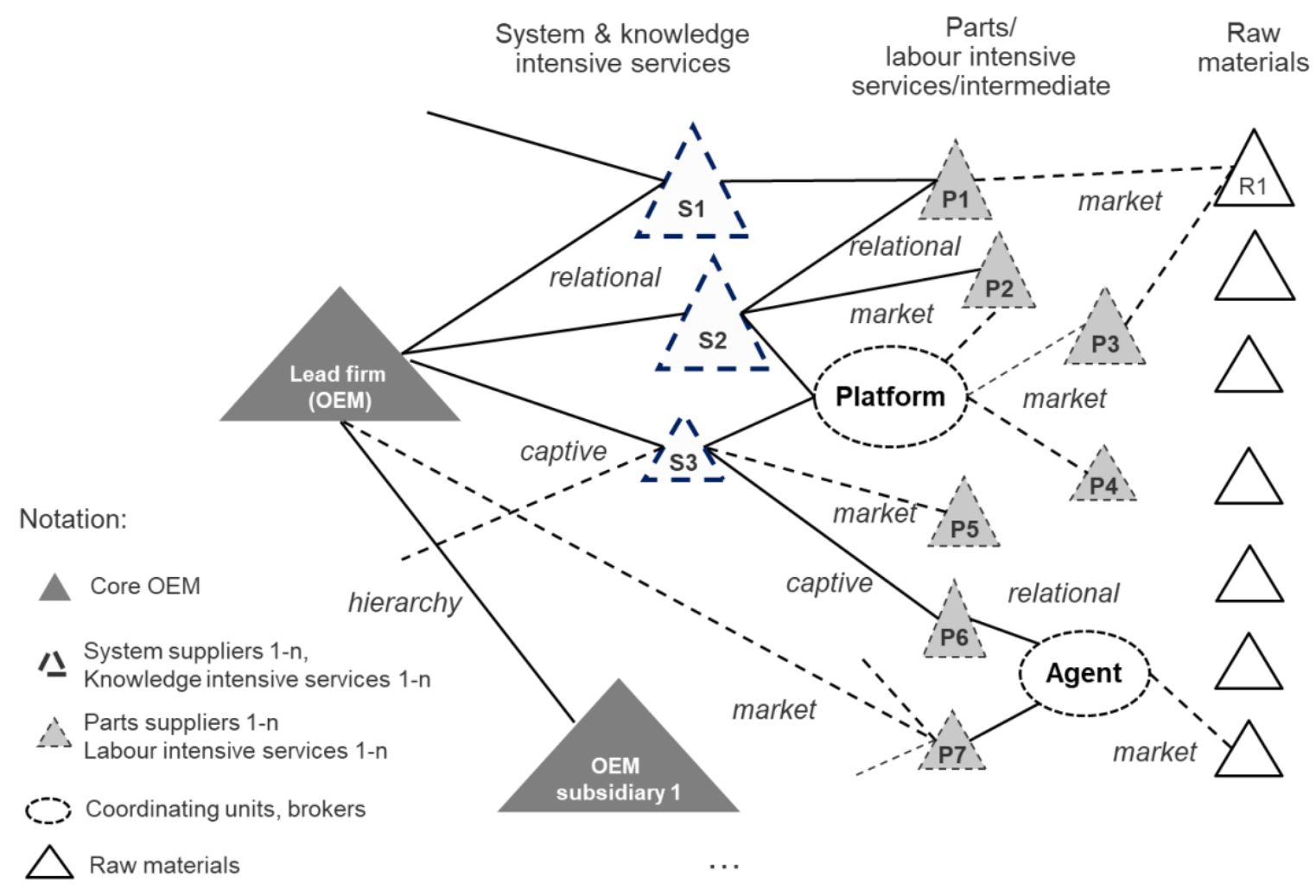


Figure 2. GVN as plural forms in the garment industry

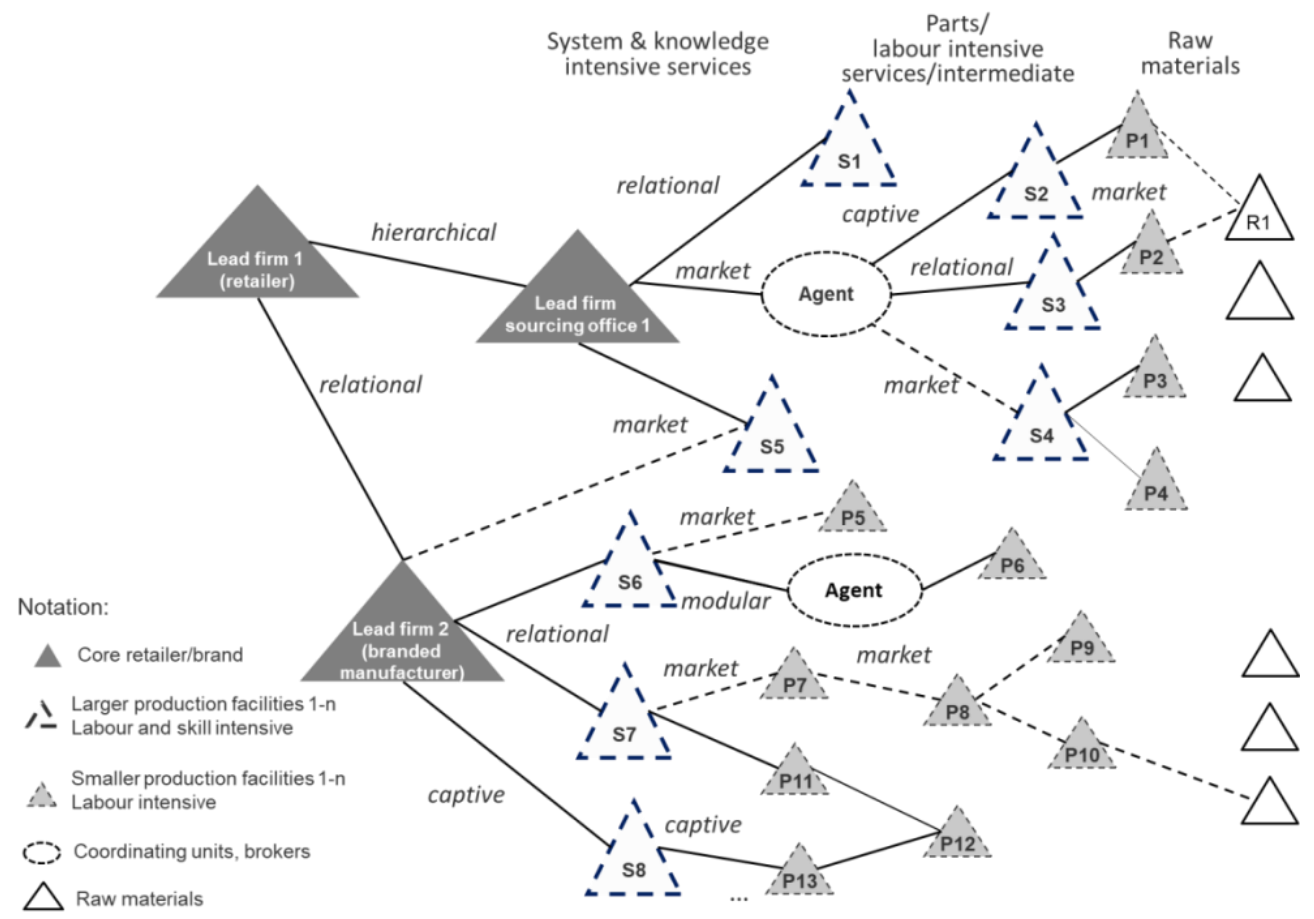

Figure 3. A network management perspective on employment relations in plural GPN

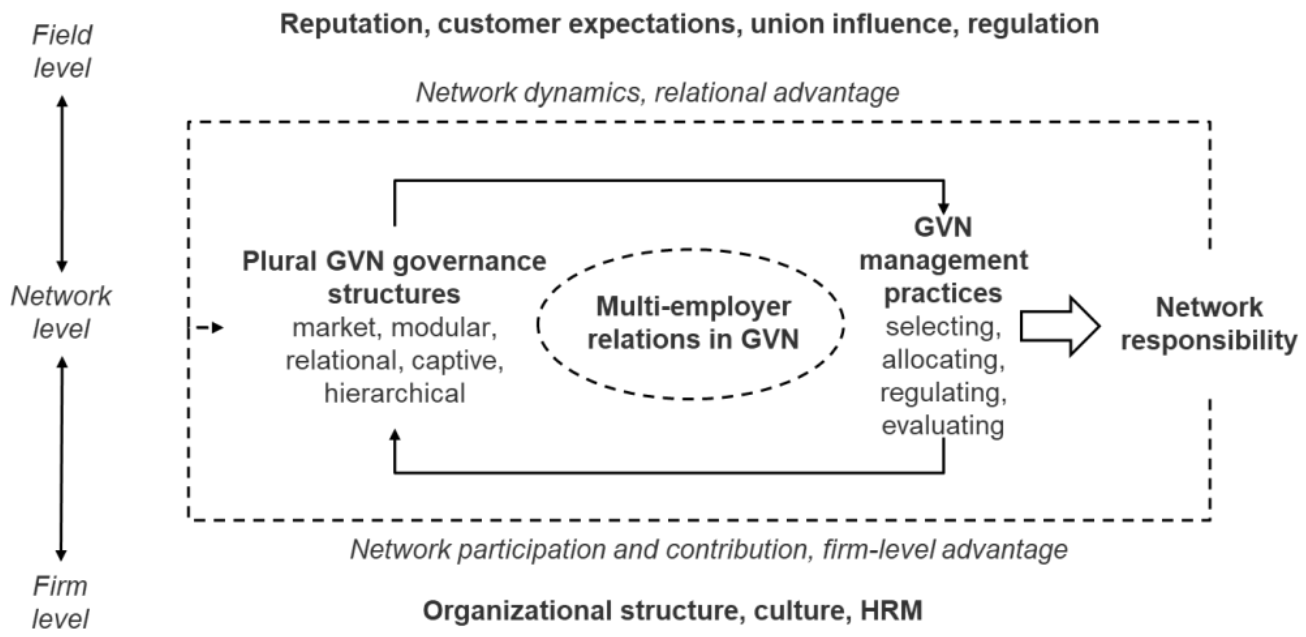

